\title{
Neuro-fuzzy Hybrid System for Monitoring Wood Moisture Content During Drying
}

\author{
Antônio José Vinha Zanuncio ${ }^{1}$ (D), Amélia Guimarães Carvalho ${ }^{1}$ (D), \\ Carlos Alberto Araújo Júnior ${ }^{2}$ (D), Maíra Reis de Assis $^{3}$ (D), \\ Liniker Fernandes da Silva ${ }^{4}$ \\ ${ }^{1}$ Universidade Federal de Uberlândia - UFU, Monte Carmelo/MG, Brasil \\ ${ }^{2}$ Universidade Federal de Minas Gerais - UFMG, Montes Claros/MG, Brasil \\ ${ }^{3}$ Universidade Federal de Lavras - UFLA, Lavras/MG, Brasil \\ ${ }^{4}$ Universidade Federal do Recôncavo da Bahia - UFRB, Cruz das Almas/BA, Brasil
}

\begin{abstract}
The heterogeneous behavior of wood during drying is a process difficult to control. The objective of this study was to evaluate the accuracy of the neuro-fuzzy hybrid system for monitoring wood moisture during drying. Eucalyptus urophylla x Eucalyptus grandis samples $(2 \times 2 \times 4 \mathrm{~cm})$ were saturated and dried in climatic chamber for 15 days. Basic density was determined by the dry mass/saturated volume ratio. Two neuro-fuzzy systems were developed to monitor wood moisture, the first based on the genetic material and drying period and the second based on basic density and drying period. The drying rate of wood samples was higher at the initial period and all reached equilibrium moisture content after 15 days. Density showed relationship with wood moisture during the study period. Both systems have the potential to monitor moisture, however, neuro-fuzzy system based on basic density and drying period showed better results and is therefore more suitable.
\end{abstract}

Keywords: air drying, basic density, Eucalyptus. 


\section{INTRODUCTION}

Drying is an important step before wood can be used (Cavalcante et al., 2016). All fresh cut timber has great amount of water (Brand et al., 2011; Zanuncio et al., 2014). This hampers wood transport (Zanuncio et al., 2017) and use for power generation (Swithenbank et al., 2011).

Environmental factors such as temperature, relative humidity and air speed (Bedane et al., 2011; Korkut et al., 2013) and wood factors, such as anatomical structure (Moya et al., 2012), basic density (Costa et al., 2014) and size (Zanuncio et al., 2015) influence wood drying. Water interacts with wood in different forms. Free water is connected by capillarity and is present in vessels and lumen fibers (Skaar, 1988), while adsorption water is attached to the cell wall by hydrogen bonds (Kollmann \& Côté, 1968). Many factors considered in wood drying make the wood behavior difficult to monitor.

Regression models can be used for wood moisture monitoring (Zanuncio et al., 2013), but the neuro-fuzzy hybrid system shows good results in various fields of knowledge, such as industry (Aliabadi et al., 2015), water treatment (Khaki et al., 2015), construction (Naji et al., 2016) and forest sciences (Vieira et al., 2014; Araújo et al., 2016), thus, this technique shows potential to be used to monitor wood moisture during drying.

Neuro-fuzzy can be considered a hybrid system, combining artificial neural networks and fuzzy logic (Fullér, 1995). Artificial neural networks are suitable to recognize patterns, but not to explain how decisions were made. Fuzzy logic systems can explain decisions with imprecise information, but they cannot automatically adjust their decision rules. Thus, a hybrid system that incorporates the advantages of these two tools can be applied to a greater number of situations or problems individually solved by one of them.

The objective of this study was to propose models with neuro-fuzzy hybrid system based on the wood characteristics and drying period to monitor wood moisture during drying.

\section{MATERIAL AND METHODS}

Seven two-years-old (A, B, C, D, E, F, G) and three seven-years-old (H, I, J) Eucalyptus urophylla $\mathrm{x}$ Eucalyptus grandis clones were selected, collecting three trees per clone. Two and seven-year-old materials were used to guarantee heterogeneity of materials, which condition facilitates the evaluation of a neuro-fuzzy hibrid system. A $40 \mathrm{~cm} \log$ was removed from 1.3 meters above ground level and then, a central plank was removed to prepare five samples $(2 \times 2 \times 4 \mathrm{~cm})$ per tree and 15 per clone (Figure 1).

Samples were saturated until mass stabilization, conditioned at $23^{\circ} \mathrm{C}$ with $50 \%$ relative humidity and weighed twice daily for wood moisture determination in dry basis using Equation 1:

$U(\%)=\left(\frac{(M u-M s)}{M s}\right) * 100$

where: $\mathrm{U}(\%)=$ wood moisture content in dry basis;

$\mathrm{Mu}=$ wet mass;

$\mathrm{Ms}=$ dry mass.

Basic density was determined by the dry mass/saturated wood volume ratio, according to NBR 11941: 2003 (ABNT, 2003). The relationship between basic density
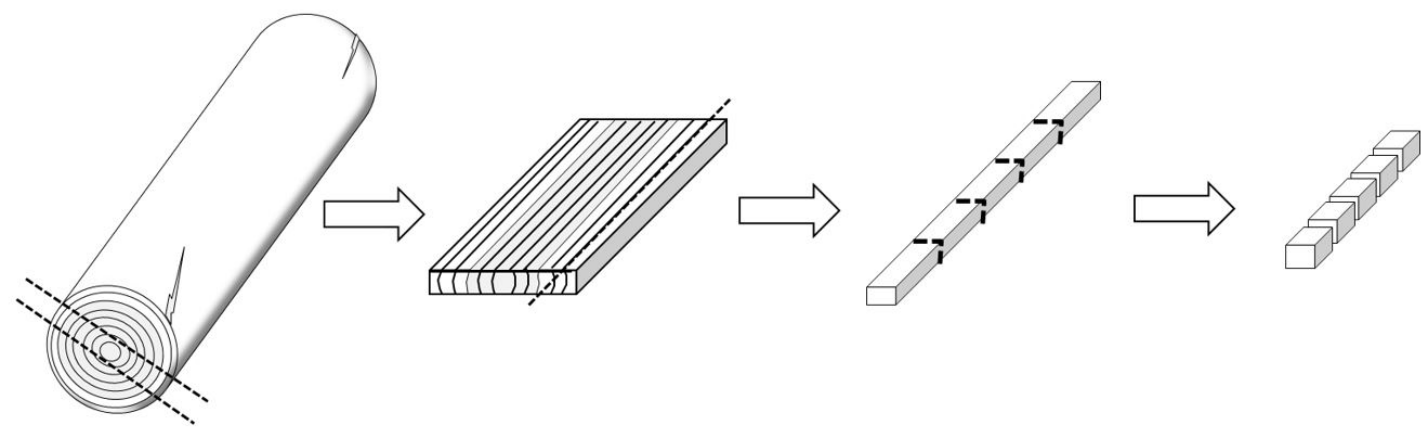

Figure 1. Removal of wood samples for saturation and drying evaluation. 
and moisture was evaluated by the Pearson correlation coefficient.

Neuro-fuzzy inference systems were used to build prediction models for moisture using the MATLAB software. The first model was based on genetic material and drying period and the second based on basic density and drying period. Six and ten membership Gaussian-type functions were used in the neuro-fuzzy modeling considering clone and drying days as input variables, respectively (Zadeh, 1965). Six membership Gaussian-type functions were used for the model considering variables basic density and drying period. The Grid Partition method was adopted due to its small number of input variables (Mesiarová-Zemánková \& Ahmad, 2010).

About $70 \%$ of data were used for training and the remaining were used to assess the quality of trained neuro-fuzzy systems. Residual graphs were used to validate the model and the correlation coefficient (r), and the root mean square error (RMSE) was calculated.

\section{RESULTS AND DISCUSSION}

The moisture content in saturated wood ranged from 129.4 to $214.6 \%$. The drying rate varied among clones, but all of them reached equilibrium moisture content ( 10.7 to $11.3 \%$ ) after 15 days of drying period (Table 1).
Moisture losses were higher at the beginning of the drying period. Clone B showed higher initial moisture and lost $107.8 \%$ moisture after one day of drying, while clone J showed the lowest initial moisture content (129.4\%) and lost $40 \%$ over the same period. During this period wood has large amount of free water, easily removed due to weak capillary connections with wood, which intensifies the drying process (Engelund et al., 2013).

The initial moisture content of clones with high basic density was lower. The higher basic density increases the wood mass per volume unit, leaving fewer spaces to be filled with water, which reduces the maximum wood moisture content (Watanabe et al., 2012). The correlation coefficient between basic density and moisture for saturated wood and after 0.5 and one day of drying period was $-0.958,-0.915$ and -0.717 , respectively. However, fewer void spaces in wood with high basic density impair the exit of water from these materials and thus, after 2.5 and 4 days of drying periods, materials with high initial moisture content reached the moisture content of other materials. Materials with lower basic density started to present lower moisture after six days of drying, a trend that continued until the end of this process.

The relationship between basic density and moisture was directly proportional at the beginning and inversely proportional below the fiber saturation point. This shows the importance of this parameter as variable in the neuro-fuzzy system to monitor and predict moisture content. The relationship between basic density and

Table 1. Basic density $\left(\mathrm{g} . \mathrm{cm}^{-3}\right)$ and moisture of ten Eucalyptus grandis $\mathrm{x}$ Eucalyptus urophylla clones in the most representative periods for the 15 days of drying (D).

\begin{tabular}{|c|c|c|c|c|c|c|c|c|c|}
\hline \multirow{2}{*}{ CL. } & \multirow{2}{*}{ B.d. } & \multicolumn{8}{|c|}{ Wood moisture content during drying (\%) } \\
\hline & & Sat. wood & $0.5 \mathrm{D}$ & $1 \mathrm{D}$ & $2.5 \mathrm{D}$ & $4 \mathrm{D}$ & 6,5 D & $9 \mathrm{D}$ & 15D \\
\hline A & 0.418 & 177.9 & 152.7 & 113.1 & 43.6 & 17.8 & 12.4 & 11.9 & 11.1 \\
\hline B & 0.372 & 214.6 & 168.8 & 106.8 & 29.0 & 13.8 & 12.0 & 11.6 & 10.9 \\
\hline $\mathrm{C}$ & 0.399 & 187.5 & 158.9 & 125.2 & 52.9 & 20.1 & 12.3 & 11.8 & 10.7 \\
\hline $\mathrm{D}$ & 0.422 & 170.0 & 127.7 & 96.7 & 34.5 & 15.6 & 12.4 & 12.0 & 11.2 \\
\hline $\mathrm{E}$ & 0.408 & 189.6 & 165.0 & 137.4 & 78.5 & 32.0 & 12.5 & 11.8 & 10.9 \\
\hline $\mathrm{F}$ & 0.469 & 150.8 & 131.8 & 107.6 & 55.2 & 24.8 & 13.1 & 12.2 & 11.3 \\
\hline G & 0.405 & 190.3 & 159.7 & 109.0 & 30.0 & 14.1 & 11.9 & 11.6 & 10.9 \\
\hline $\mathrm{H}$ & 0.492 & 135.8 & 117.0 & 96.6 & 51.2 & 22.6 & 12.8 & 11.9 & 11.0 \\
\hline I & 0.484 & 136.6 & 115.0 & 77.8 & 23.2 & 14.8 & 12.2 & 12.0 & 11.1 \\
\hline $\mathrm{J}$ & 0.537 & 129.4 & 108.7 & 79.4 & 33.2 & 18.7 & 13.0 & 12.1 & 11.3 \\
\hline $\mathrm{r}^{*}$ & - & -0.958 & -0.915 & -0.717 & -0.134 & 0.108 & 0.663 & 0.776 & 0.643 \\
\hline
\end{tabular}

$\mathrm{CL} .=$ Eucalyptus grandisx Eucalyptus urophylla clone; B.d.= basic density; Sat. wood $=$ Saturated wood; D= Days; $\mathrm{r}^{*}=$ Pearson correlation coefficient between basic density and respective wood moisture. 

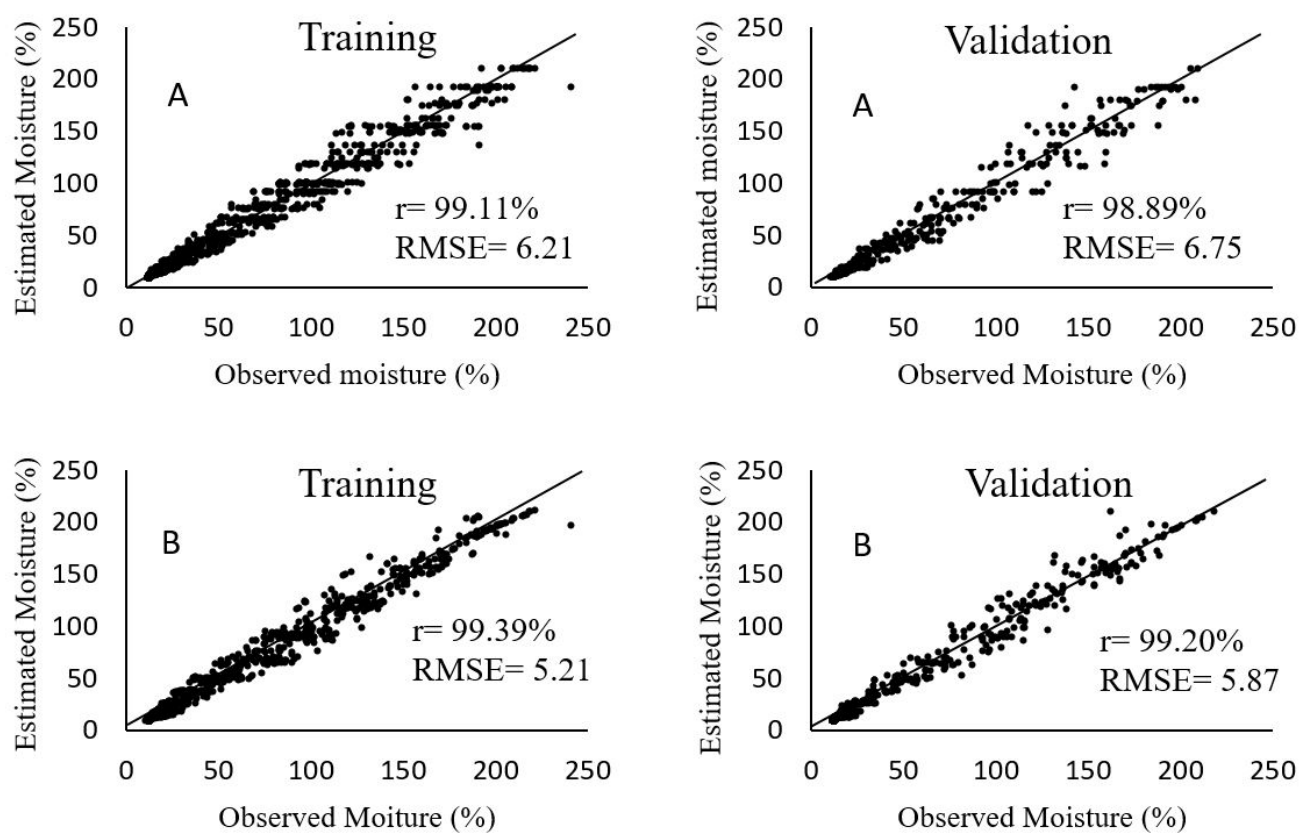

Figure 2. Relationship between observed values and those estimated by the neuro-fuzzy system. (A) neuro-fuzzy system based on clone and drying period; (B) = neuro-fuzzy system based on basic density and drying period; $\mathrm{r}=$ correlation coefficient; RMSE $=$ root mean square error.

moisture was also reported for Eucalyptus urophylla logs (Zanuncio et al., 2015) and Cryptomeria japonica lumber (Watanabe et al., 2012).

Both neuro-fuzzy systems showed similar correlation coefficient and root mean square error for training and validation (Figure 2). The largest deviations were found for wood with higher moisture, which data were more heterogeneous, making the prediction of results using the neuro-fuzzy system more difficult. However, networks predicted the results without trend or heterocedasticity, highlighting their quality and potential for monitoring the moisture content of wood during the drying process.

Neuro-fuzzy systems based on basic density and drying period showed higher accuracy. Basic density can vary within the same clone, resulting in different drying rates. Neuro-fuzzy systems based on basic density can access wood characteristics more accurately, increasing the moisture prediction efficiency. Furthermore, neuro-fuzzy systems based on clone and drying period can be used only for genetic materials used in its construction, but neuro-fuzzy systems based on basic density and drying period can be used for all wood materials. The use of the basic density was also effective to monitor the moisture of E. urophylla logs during 90 days of air drying (Zanuncio et al., 2015).

\section{CONCLUSION}

The wood drying behavior varies with the genetic material and drying period, with higher rates during the first drying days and in low-density materials. Both neuro-fuzzy systems were effective to monitor and predict wood moisture; however, system based on basic density and drying period was more efficient and thus, more adequate for this process.

\section{SUBMISSION STATUS}

Received: 18 apr., 2017

Accepted: 25 jan., 2018

\section{CORRESPONDENCE TO}

\section{Antônio José Vinha Zanuncio}

Instituto de Ciências Agrárias, Universidade Federal de Uberlândia - UFU, R. Goiás, 2000, CEP 38500-000, Monte Carmelo, MG, Brasil e-mail: ajvzanuncio@yahoo.com.br 


\section{FINANCIAL SUPPORT}

Conselho Nacional de Desenvolvimento Científico e Tecnológico; Coordenação de Aperfeiçoamento de Pessoal de Nível Superior; Fundação de Amparo à Pesquisa do Estado de Minas Gerais.

\section{REFERENCES}

Aliabadi M, Golmohammadi R, Khotanlou H, Mansoorizadeh M, Salarpour A. Artificial neural networks and advanced fuzzy techniques for predicting noise level in the industrial embroidery workrooms. Applied Artificial Intelligence 2015; 29(8): 766-785. http://dx.doi.org/10.1080/08839 514.2015.1071090.

Araújo CA Jr, Silva LF, Silva ML, Leite HG, Valdetaro EB, Donato DA et al. Modelling and forecast of charcoal prices using a neurofuzzy system. Revista Cerne 2016; 22(2): 151-158.

Associação Brasileira de Normas Técnicas - ABNT. ABNT: NBR 11941:2003 - Madeira - Determinação da densidade básica. Rio de Janeiro: ABNT; 2003. 6 p.

Bedane AH, Afzal MT, Sokhansanj S. Simulation of temperature and moisture changes during storage of woody biomass owing to weather variability. Biomass and Bioenergy 2011; 35(7): 3147-3151. http://dx.doi. org/10.1016/j.biombioe.2011.04.008.

Brand MA, Muñiz GIB, Quirino WF, Brito JO. Storage as a tool to improve wood fuel quality. BiomassandBioenergy 2011; 35(7): 2581-2588

Cavalcante AA, Naveiro RM, Costa SS. Secagem da madeira de louro preto (Nectandracuspidata) em estufa de micro-ondas. Floresta e Ambiente 2016; 23(3): 427-434. http://dx.doi.org/10.1590/2179-8087.012412.

Costa VE, Rezende MA, Rodrigues VA. Conversion between basic density and apparent density at any moisture content in Eucalyptus grandis. Holzforschung 2014; 68(8): 981-986. http://dx.doi.org/10.1515/hf-2013-0211.

Engelund ET, Thygesen LG, Svensson S, Hill CAS. A critical discussion of the physics of wood-water interactions. Wood Science and Technology 2013; 47(1): 141-161. http:// dx.doi.org/10.1007/s00226-012-0514-7.

Fullér R. Neural fuzzy systems. Abo: Abo Akademi University; 1995

Khaki M, Yusoff I, Islami N. Application of the artificial neural network and neuro-fuzzy system for assessment of groundwater quality. Clean - soil, air. Water (Basel) 2015; 43(4): 551-560.

Kollmann FFP, Côté WA. Principles of wood science and technology: solid wood. New York: Springer, 1968. 592 p. http://dx.doi.org/10.1007/978-3-642-87928-9.
Korkut S, Ünsal O, Kocaefe D, Aytin A, Gökyar A. Evaluation of kiln-drying schedules for wild cherry wood (Cerasus avium). Maderas. Ciencia y Tecnología 2013; 15(3): 281-292.

Mesiarová-Zemánková A, Ahmad K. T-norms in subtractive clustering and backpropagation. International Journal of Intelligent Systems 2010; 25: 909-924.

Moya R, Tenorio C, Meyer I. Influence of wood anatomy on moisture content, shrinkage and during defects in Vochysiaguatemalensis Donn Sm. Scientia Forestalis 2012; 40(94): 249-258.

Naji S, Shamshirband S, Basser H, Keivani A, Alengaram UJ, Jumaat MZ et al. Application of adaptive neuro-fuzzy methodology for estimating building energy consumption. Renewable \& Sustainable Energy Reviews 2016; 53(1): 1520-1528. http://dx.doi.org/10.1016/j.rser.2015.09.062.

Skaar C. Wood-water relations. New York: Springer-Verlag; 1988. 263 p. http://dx.doi.org/10.1007/978-3-642-73683-4.

Swithenbank J, Chen Q, Zhang X, Sharifi V, Pourkashanian M. Wood would burn. Biomass and Bioenergy 2011; 35(3): 999-1007. http://dx.doi.org/10.1016/j.biombioe.2010.12.026.

Vieira FHA, Affonso C, Alves MCS. Application of neurofuzzy inference system on wood identification. Applied Mechanics and Materials 2014; 590: 667-671. http://dx.doi. org/10.4028/www.scientific.net/AMM.590.667.

Watanabe K, Kobayashi I, Kuroda N. Investigation of wood properties that influence the final moisture content of air-dried sugi (Cryptomeria japonica) using principal component regression analysis. Journal of Wood Science 2012; 58(6): 487-492. http://dx.doi.org/10.1007/s10086012-1283-5.

Zadeh LA. Fuzzy sets. Information and Control 1965; 8(3): 338-353. http://dx.doi.org/10.1016/S0019-9958(65)90241-X.

Zanuncio AJV, Carvalho AG, Silva LF, Lima JT, Trugilho PF Silva JRM. Predicting moisture content frombasic density and diameter during air drying of Eucalyptus and Corymbia logs. Maderas. Ciencia y Tecnología 2015; 17(2): 335-344. http://dx.doi.org/10.4067/S0718-221X2015005000031.

Zanuncio AJV, Carvalho AG, Silva MG, Lima JT. Importance of wood dry in gtothe forest transport and pulp production. Revista Ceres 2017; 23(2): 147-152.

Zanuncio AJV, Monteiro TC, Lima JT, Andrade HB, Carvalho AG. Drying biomass for energy use of Eucalyptus urophylla and Corymbia citriodora logs. Bio Resources 2013; 8(4): 5159-5168. http://dx.doi.org/10.15376/ biores.8.4.5159-5168.

Zanuncio AJV, Lima JT, Monteiro TC, Trugilho PF, Lima FS. Curva característica de secagem da madeira de Tectona grandis e Acacia mangium ao ar livre. Floresta e Ambiente 2014; 22(1): 117-123. http://dx.doi.org/10.1590/21798087.037913 